\title{
Effectiveness of Biofeedback Therapy as Conservative Choice for Management of Female Stress Urinary Incontinence
}

1 Ana Marija Hošnjak

1 Sanja Ledinski Fičko

1 Martina Smrekar

1 Boris Ilić

2 Štefanija Kolačko

${ }^{3}$ Marina Jurić

1 University of Applied Health Sciences, Department of Nursing, Mlinarska cesta 38, 10000 Zagreb, Croatia

2 Clinical Hospital "Sveti Duh", Sveti Duh 64, 10000 Zagreb, Croatia

${ }^{3}$ Children`s Hospital Zagreb, Klaićeva 16, 10000 Zagreb, Croatia

Article received: 05.07.2017.

Article accepted: 03.11.2017.

Author for correspondence:

Ana Marija Hošnjak

University of Applied Health Sciences,

Mlinarska cesta 38, 10000 Zagreb

Phone: + 385914595714

Email: anamarija.hosnjak@zvu.hr

DOI: $10.24141 / 2 / 1 / 1 / 9$

Keywords: stress urinary incontinence, biofeedback, women

\section{Abstract}

The aim of this study is to evaluate the efficacy of biofeedback (BF) therapy in females with stress urinary incontinence by a systematic review of available literature database.

Materials and methods. A search of the MEDLINE database in order to find articles related to biofeedback therapy for treating incontinence. The keywords which were used to search the database were: "biofeedback", "women", "stress urinary incontinence". Analyses included full-length, peer-reviewed articles reporting on outcomes of treatment of stress urinary incontinence (SUI) using BF in 18-year-old women and older, from any country, treated in any care setting. The inclusion criteria were that it was an original research, not older than five years and written in English.

Results. The search of the database yielded a total of 123 articles. Further analysis determined that 32 articles were suitable with respect to this study's search criteria. Finally, the analysis included 5 articles. The studies are from different parts of the world: Egypt, Poland, China, Malaysia and Japan. Two articles are from 2013 and 2015, and one was published in 2016. Three studies evaluated the efficacy of biofeedback therapy (BF therapy) versus self-performed Kegel exercises, and two studies compared biofeedback therapy with electrical stimulation.

Conclusion. Although almost all studies (4 of the 5 analysed) report a positive impact of biofeedback therapy in treating SUI, further research on a more homogeneous group, employing standardized protocols, should be conducted in the future. 


\section{Introduction}

Urinary incontinence $(\mathrm{UI})$ is a considerable psychological and physical morbidity a millions people worldwide suffer from today (1). It is estimated that the prevalence is between $25 \%$ and $45 \%$ (2), and it increases with age. It occurs twice more often in women than in men: $13.1 \%$ versus $5.4 \%(3)$, until the age of 80 , after which the prevalence is equal for both genders (4).

The International Continence Society (ICS) defines urinary incontinence as the complaint of involuntary leakage of urine $(5,6)$ and suggests a classification according to the presence of symptoms and pathophysiological mechanisms of occurrence.

The most prevalent form of urinary incontinence among women, in $50 \%$ of cases, is stress incontinence $(7,8)$. SUI is the most common type of incontinence in women (9-12), and occurs due to increased intra-abdominal pressure during sneezing, coughing, running, laughing or exertion of some greater physical effort $(7,9)$. SUI affects all age groups, and occurs most commonly in women between 15 and 64 years of age (10). It is a considerable medical and social problem which reduces quality of life, especially in younger women (7), because of the stigma which still exists.

Women suffering from UI rarely seek medical support, which is especially prominent in Europe where $75 \%$ of women never sought any treatment (2), which confirms that urinary incontinence is still a taboo topic. Older women still think that $\mathrm{UI}$ is a normal physiological state related to the consequences of aging (5), while others believe that surgery is the only available treatment option.

As a consequence, local candida infection, cellulitis, skin irritation, insomnia and fatigue due nocturia may occur (5). Furthermore, self-image dysfunction, avoidance of social activities, traveling, recreation, and interpersonal and sexual dysfunction often occur due to embarrassment. Depression and anxiety often accompany urinary incontinence $(5,13)$.

\section{Pathophysiology of Urinary Incontinence}

The pelvic floor is a complex, three-dimensional mechanical system which consists of several components. The anatomical structures responsible for supporting the pelvic floor are the bony pelvis and endopelvic fascia, pelvic viscera, pelvic diaphragm, urogenital diaphragm, and levator ani muscles $(14,15)$.

Urine continence is defined as the ability to retain urine in the urinary bladder between episodes of voluntary micturition. Continence depends on the coordinated activity of the central and peripheral nervous system, urinary bladder muscles (detrusors) and anatomical relations between the neck of the urinary bladder and the urethra. When detrusors cannot retain urine inside the urinary bladder due to weakened function, and a patient cannot affect micturition voluntarily since urinary leakage occurs without the patient's awareness of it, then we can conclude that it is a case of incontinence. Multiple factors can cause incontinence, such as hormonal therapy, menopause, weakened pelvic muscles due to childbirth, some drugs, infections, surgical procedures undertaken on the genitourinary tract, nerve damage, BMI above $30(5,10,16)$, and sport activities which require frequent jumping (16).

\section{Treatments for UI}

Treatment for $\mathrm{UI}$ includes surgery and conservative methods, and depends on the type of incontinence, seriousness of the problem and causes. Conservative methods are recommended as a first line of treatment in the management of stress, urge (7) and mixed UI (17). The available non-surgical, conservative treatment methods include lifestyle modification (a voiding diary, refraining from smoking, weight loss), Kegel exercises (exercises to strengthen the tone and contraction of pelvic floor muscles - PFM), behavioural interventions (changing behaviour to eliminate or minimize the problem, bladder training), biofeedback (use of urethral, vaginal or rectal sounding for creating visual or auditory signals when pelvic muscles are contracted), electrical stimulation and a combination of several different methods (11). Kegel exercises with biofeedback $(4)$ or electrical stimulation $(8,18)$ and weighted vaginal cones (18) are usually recommended.

Non-surgical treatment for $\mathrm{UI}$ is effective, cheap, and easy to use in case of a milder stage of incontinence with minimal side effects. All these methods can be used in parallel with surgical methods. 


\section{Biofeedback}

Biofeedback (BF) is a technique by which a patient can affect a certain physiological function by using signals from their own body, and not just those under the control of the "voluntary" nervous system, but also those under the control of the "involuntary", that is, the autonomic nervous system. Patient education on using BF requires more time, but the benefits are long-term because the patient becomes much more responsible when it comes to performing exercises when there is an objective medical finding (10). Also, $\mathrm{BF}$ is a non-invasive procedure in contrast with surgical treatment and it is the first option for the treatment of SUI in many cases (8).

The use of $\mathrm{BF}$ is based on the view that an additional stimulus in the form of feedback helps the development of motor skills (19).

$\mathrm{BF}$ as a method of treating incontinence consists of monitoring devices which provide feedback on PFM activity. If an internal sensor is used, the sensor is introduced into the vagina, the rectum (or both) and the urethra (19). If an external sensor is used, adhesive electrodes are placed on the skin, onto the muscle.

The purpose of those sensors is to provide women with information on the strength of contraction and relaxation of the PFM by acoustic, visual or tactile signals, which enables women to become aware of and gain control over their own contractions. This means that weaker muscles can be better activated on demand, muscles that are too tense can relax, and overall muscle activity may be coordinated in a better way. Electrodes can be placed on the abdomen, thigh or gluteus area with the purpose of checking for involuntary contraction of other muscles when feeling the urge to urinate. BF is a very useful method in promoting correct contraction control by means of visualization of muscle activity (8). BF therapy can be used as an independent method or in combination with other methods of behavioural therapy, most often with Kegel exercises $(4,8)$ because many women are unaware of how to contract their PFM without external signals (8), and therefore often contract abdominal or gluteal muscles. Previous study has shown that about one third of women are unable to contract the PFM voluntarily and avoid raising abdominal pressure (20).

Providing feedback on the exercise effectiveness through graphs on the monitor encourages further workouts.
BF therapy is safe and effective. Patient education may take time, but it makes the patient more responsible and less passive regarding the treatment process (10). Therapy lasts from half an hour to one hour for a period of a few weeks, and is supervised by a multidisciplinary team composed of nurses, physiotherapists and doctors (21).

The aim of this systematic review is to examine the effectiveness of BF therapy for SUI in women.

\section{Methods}

In conducting this systematic review, we searched the MEDLINE (via PubMed) database for relevant articles that investigated the effectiveness of biofeedback therapy for women with stress urinary incontinence (SUI). The keywords used to search the database were: "biofeedback", "women", "stress urinary incontinence". For better filtering of results, the terms were placed in quotation marks. The selection criteria included the following:

1. full-length, peer-reviewed articles reporting on outcomes of therapy for SUI using BF in conjunction with other behavioural techniques (Kegel exercises, trans-vaginal electrical stimulation)

2. studies with 18-year-old female participants and older, from any country, affected by SUI, and treated in any care setting (home, hospital, outpatient department)

3. only original research published within the last 5 years, reporting on human subjects, and written in English was included

4. empirical studies conducted using qualitative or qualitative methods were excluded

5. empirical studies including women in the postpartum period, postoperative period, pregnant women, women with neurological disorders and men were excluded,

6. unpublished studies and abstracts were excluded. The selection criteria are shown in Table 1.

During a search of the database by keywords in March 2017, 123 articles were found in total. Further analysis found that 32 articles matched the in- 


\begin{tabular}{ccc} 
& Table 1. Inclusion and exclusion criteria & \\
SELECTION CRITERIA & INCLUSION & EXCLUSION \\
& Original research & Systematic review \\
RRTICLE CATEGORY & Review article \\
& & Report \\
& Editorial \\
KEYWORDS & "Biofeedback" & Postpartum \\
& "Women" & Postoperative \\
DATE OF PUBLISHING & Pregnant women \\
LANGUAGE & 2012-2017 & Neurological disorders \\
& English & Before 2012 \\
\hline
\end{tabular}

clusion criteria. Randomized clinical trials referring to performing Kegel exercises with or without BF were also included in the analysis. It was important that the articles were an original study, available in full version, which resulted in 8 articles in total. Further analysis resulted in the exclusion of three articles: one investigated pharmacotherapy, another investigated the effect of BF in women with multiple sclerosis, and another investigated the influence of $\mathrm{BF}$ on incontinence in the postpartum period. Figure 1 shows the characteristics of the selected articles.

\section{Results}

A systematic review of literature yielded 5 articles which matched the selection criteria for a more detailed analysis. Only one study included a double-blind test. The studies are from different parts of the world: Egypt, Poland, China, Malaysia and Japan. Two articles are from 2013 and 2015, and one was published in 2016.

The analysis of the articles, description and aims of the research, methodology and results obtained are given in Table 2.

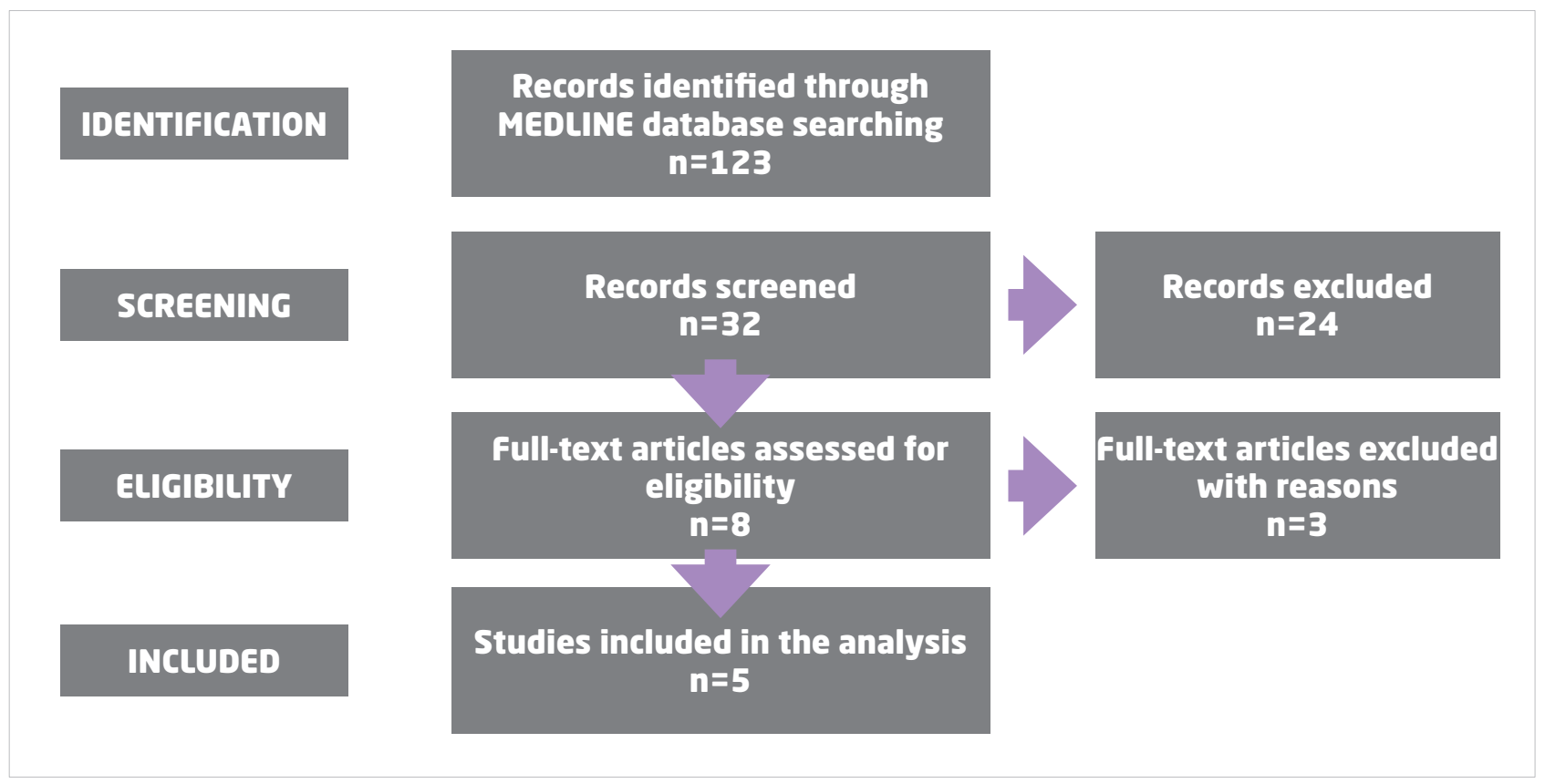




\section{Table 2. Characteristics of the selected studies}

\begin{tabular}{ll}
$\begin{array}{c}\text { Author / Year } \\
\text { Country }\end{array}$ & \multicolumn{1}{c}{ Title } \\
Hirakawa et al / & Randomized \\
2013 & controlled trial \\
Japan (7) & $\begin{array}{l}\text { of pelvic floor } \\
\text { muscle training }\end{array}$ \\
& with or without \\
& BF for urinary \\
& incontinence
\end{tabular}

Description and Purpose of Research

Results

To compare the effects of pelvic floor muscle training with or without $\mathrm{BF}$

Duration of research: 12 weeks

$\mathrm{N} 1=19$ (Kegel exercises + biofeedback)

$\mathrm{N} 2=20$ (Kegel exercises)

Methodology

A) Kings Health Questionnaire (KHQ) and International Consultation on Incontinence Questionnaire-Short Form (ICIQ-SF)

\section{B) Pad test}

\section{C) A voiding diary}
D) Measurement of pelvic floor muscle strength by perineometry
A) KHQ
$\mathrm{N} 1=p<0.05$
$\mathrm{N} 2=p<0.05$
ICIQ-SF N1 $=p<0.05$
$\mathrm{N} 2=p<0.05$

B) No significant differences between the two groups
C)
N1 $p=0.054$
N2 $p<0.05$
D)
N1 $p<0.00$
N2 $p<0.01$

${ }^{\star} p<0.05$ was considered statistically significant

\section{Terlikowski / \\ 2013}

Transvaginal

electrical

Poland (10) with

surface EMG

biofeedback

in managing

stress urinary

incontinence

in women of premenopausal age: a doubleblind, placebocontrolled, randomized

clinical trial
To evaluate the results of conservative treatment using transvaginal electrical stimulation with biofeedback (TVES + BF)

Duration of research: 16 weeks $\mathrm{N} 1=64($ TVES $+\mathrm{BF})$ $\mathrm{N} 2=29$ (Placebo TVES $+\mathrm{BF})$

\section{Methodology}

A) Pad test (pads were weighed before and after 6 hours of use, except for the pad used during nightly sleep, which could be used all night)

\section{B) Urodynamic test}

\section{C) Incontinence quality of life questionnaire (I-QOL)}

A) > 0 week N1, N2 $p=0.324$

$>8$ week N1 $p=0.022$

$$
\begin{aligned}
& >16 \text { week N1 } \\
& p=0.024
\end{aligned}
$$

B) > no significant difference was found between the groups in urodynamic data before and after treatment

$$
\begin{gathered}
\text { C) }>0 \text { week N1, N2 } \\
p=0.241 \\
>8 \text { week N1 } \\
p=0.004 \\
>16 \text { week N1 } \\
p<0.001
\end{gathered}
$$




\begin{tabular}{|c|c|c|c|}
\hline $\begin{array}{l}\text { Author / Year } \\
\text { Country }\end{array}$ & Title & Description and Purpose of Research & Results \\
\hline $\begin{array}{l}\text { Ibrahim et al / } \\
2015 \\
\text { Egypt (22) }\end{array}$ & $\begin{array}{l}\text { Efficacy of BF- } \\
\text { assisted pelvic } \\
\text { floor muscle } \\
\text { training in } \\
\text { females with } \\
\text { pelvic floor } \\
\text { dysfunction }\end{array}$ & $\begin{array}{l}\text { To evaluate the efficacy of BF with Kegel } \\
\text { exercises } \\
\text { Duration of research: } 12 \text { weeks } \\
\text { N1=24 (Kegel exercises + BF in clinical } \\
\text { environment) } \\
\text { N2=23 (Kegel exercises in home } \\
\text { environment) } \\
\text { Methodology } \\
\text { A) Pelvic floor questionnaire (PFQ) } \\
\text { B) Vaginal manometry (VM) }\end{array}$ & $\begin{array}{l}\mathrm{N} 1 p=0.029 \\
\mathrm{~N} 1 p=0.023 \\
{ }^{*} \mathrm{p}<0.05 \text { was considered statistically significant }\end{array}$ \\
\hline $\begin{array}{l}\text { Ong et al / } \\
2015 \\
\text { Malaysia (23) }\end{array}$ & $\begin{array}{l}\text { Using the } \\
\text { Vibrance } \\
\text { Kegel Device } \\
\text { with pelvic } \\
\text { floor muscle } \\
\text { exercise for } \\
\text { stress urinary } \\
\text { incontinence: } \\
\text { a randomized } \\
\text { controlled pilot } \\
\text { study }\end{array}$ & $\begin{array}{l}\text { To evaluate the effectiveness of } \\
\text { Kegel exercises performed with a new } \\
\text { biofeedback device, compared to Kegel } \\
\text { exercises alone } \\
\text { Duration of research: } 16 \text { weeks } \\
\mathrm{N} 1=19 \text { (Kegel exercises) } \\
\mathrm{N} 2=21 \text { (Kegel exercises + BF) } \\
\text { Methodology } \\
\text { A) Australian pelvic floor } \\
\text { questionnaires (APFQ) }\end{array}$ & 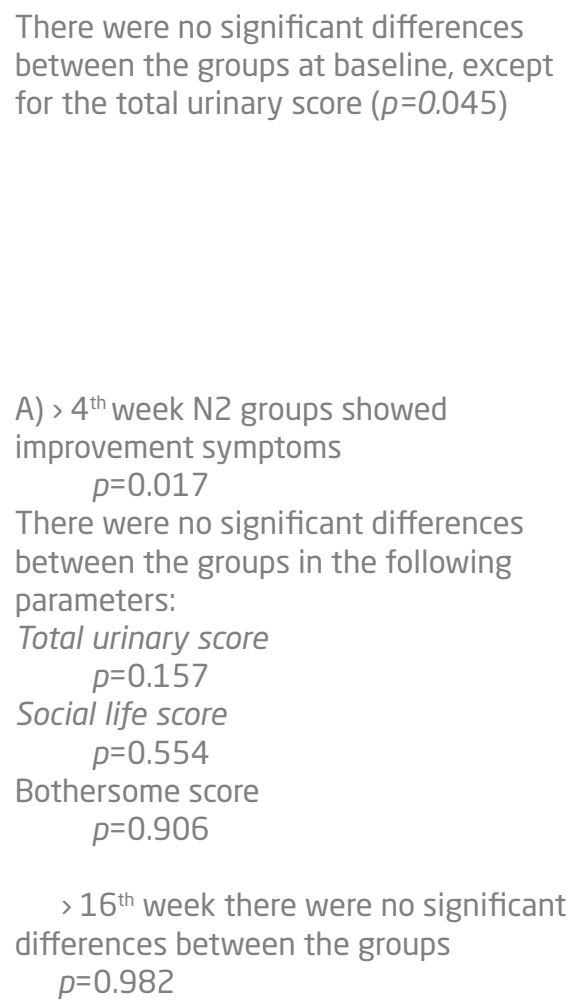 \\
\hline & & $\begin{array}{l}\text { B) Modified Oxford Scales for pelvic } \\
\text { floor muscle strength (MOS) }\end{array}$ & $\begin{array}{l}\text { B) }>4^{\text {th }} \text { week MOS showed statistically } \\
\text { significant differences between the } \\
\text { groups } \\
\quad P=0.027 \\
\quad>16^{\text {th }} \text { week differences stayed } \\
\text { statistically significant } \\
\quad P=0.03 \\
{ }^{*} P<0.05 \text { was considered statistically significant }\end{array}$ \\
\hline
\end{tabular}




\begin{tabular}{|c|c|c|c|}
\hline $\begin{array}{l}\text { Author / Year } \\
\text { Country }\end{array}$ & Title & Description and Purpose of Research & Results \\
\hline $\begin{array}{l}\text { Yeung et al / } \\
2016 \\
\text { Kina (24) }\end{array}$ & $\begin{array}{l}\text { Evaluation } \\
\text { of treatment } \\
\text { outcomes in } \\
\text { pelvic floor } \\
\text { muscle training } \\
\text { with BF versus } \\
\text { intra-vaginal } \\
\text { electrical } \\
\text { stimulation } \\
\text { in women } \\
\text { with urinary } \\
\text { incontinence } \\
\text { in Hong Kong } \\
\text { Pamela Youde } \\
\text { Nethersole } \\
\text { Eastern } \\
\text { Hospital }\end{array}$ & $\begin{array}{l}\text { To evaluate the treatment outcomes and } \\
\text { effectiveness of BF pelvic floor muscle } \\
\text { training against intra-vaginal electrical } \\
\text { stimulation } \\
\text { Duration of research: } 12 \text { weeks } \\
\text { N1=62 (intra-vaginal electrical } \\
\text { stimulation, IVES) } \\
\text { N2= } 45 \text { (biofeedback, BF) } \\
\text { Methodology } \\
\text { A) Symptom analysis (SA) } \\
\text { B) Quality of life questionnaire (KLQ) } \\
\text { C) Pad test (PT) }\end{array}$ & $\begin{array}{l}\text { A) SA : N1 }=p<0.05 \\
: \mathrm{N} 2=p<0.05 \\
\text { B) KLQ : N1 }=p<0.05 \\
: \text { N2 }=p<0.05 \\
\text { C) PT number of pads used per day } \\
\text { reduced from: } \\
: \text { N1 from } 2.4 \text { to } 1.2 p<0.05 \\
: \text { N2 from } 2.3 \text { to } 2.1 p<0.05\end{array}$ \\
\hline
\end{tabular}

The analysis of five different studies, conducted all over the world and published in the past 5 years, was carried out. The studies investigated the effects of BF therapy on urinary incontinence. All studies included women ( $n=326)$ suffering from urinary stress incontinence. Three studies evaluated the efficacy of biofeedback therapy (BF therapy) versus self-performed Kegel exercises (7, 22, 23), and two studies compared biofeedback therapy with electrical stimulation $(10,24)$.

In 2013, Hirakawa et al. compared the effects of pelvic floor muscle training with or without BF. A total of 39 participants with SUI were randomized into two groups: Kegel exercises with BF (KE + BF) or without $\mathrm{BF}(\mathrm{KE})$. By means of the King's Health Questionnaire (KHQ) and International Consultation on Incontinence Questionnaire-Short Form (ICIQ-SF), they measured quality of life as the primary outcome. A voiding diary, 1-h pad test and manometry were used to get an insight into secondary outcomes.

The difference between the primary and secondary outcomes was assessed before and after 12 weeks of exercise training. The study statistically showed that Kegel exercises, with or without BF, significantly affect the improvement of subjective symptoms (improved quality of life $(p<0.05))$ and objective symp- toms (increased strength of the PFM $p<0.01$ ). The leakage volume in the 1-h pad test did not decrease in either group. The number of incontinence episodes decreased in the KE group $(p<0.05)$. It also decreased in the KE + BF group, but the difference was not statistically significant ( $p=0.054$ ). $78.2 \%$ of the women in the KE group and $69.6 \%$ of the women in the KE + BF group reported an improvement in incontinence (7).

A similar pattern and variables were explored by lbrahim (2015) and Ong (2015), but they proved a statistically significant difference between the two groups of respondents $(22,23)$.

Ibrahim et al. investigated the efficacy of BF-assisted Kegel exercises in females with pelvic floor dysfunction in clinical environment in contrast with women who performed Kegel exercises independently at home. Females with neurological conditions, gynaecological or genitourinary surgery and postpartum incontinence were excluded. They proved a statistically significant difference between the investigated groups, and described that biofeedback-assisted Kegel exercises were an effective therapy compared to Kegel exercises alone. As a reason, they mentioned that BF affects the reduction of symptoms in a shorter period and allows exercising of the PFM 
more properly. As many as 19 (79.2\%) participants of $\mathrm{KE}+\mathrm{BF}$ reported improvement of symptoms after 9.7 weeks, compared to 7 participants (31.8\%) who reported improvement after 11.8 weeks in KE group. Improved ability to correctly isolate the PFM contraction was reported by 15 participants from the KE + $\mathrm{BF}$ group, compared to only 3 participants in the KE group. Greater efficacy of biofeedback in combination with Kegel exercises, when contrasted with Kegel exercises alone, is also demonstrated by manometry, which was performed at the end of the research. Significantly greater improvement was thereby shown on part of the $\mathrm{KE}+\mathrm{BF}$ group (22.3\% compared to $6.1 \%)(22)$.

Ong et al. (2015) compared the effectiveness of Kegel exercises performed in combination with the new BF device to Kegel exercises alone (18). They proved that BF therapy resulted in significant early improvement of the symptoms of stress incontinence $(p=0.035)$, and that pelvic muscle strength was significantly better $(p=0.025)$ after 4 weeks of training. The subjective rate of improvement was similar in both groups (62.5\% for KE: $61.9 \%$ for BF group), $p=0.742(23)$.

Yeung and associates (2016) compared how Kegel exercises + BF affect pelvic floor muscles as opposed to intra-vaginal electrical stimulation (24). Participants from the BF group achieved better results in assessing urinary symptoms, and reported greater satisfaction with life quality. This may be because $\mathrm{BF}$ is more comfortable than intra-vaginal stimulation, as reported by the participants. However, in the case of intra-vaginal electrical stimulation, the number of pads used per day decreased from 2.4 to 1.2 , in contrast with the reduction from 2.3 to 2.1 in the BF group. The results showed that both methods were equally effective and that they do not differ in a statistically significant manner (24).

Similar results were also obtained by Terlikowski three years earlier in an investigation of the effects of trans-vaginal electrical stimulation with BF between the active and placebo groups. Using the double-blind test, Terlikowski compared the effect of trans-vaginal electrical stimulation + BF between the active and placebo groups. From the active group, $39 \%$ of participants objectively showed a reduction in the number of incontinence episodes, while in the placebo group an objective improvement was not achieved. Subjectively, $45.3 \%$ of female patients in the active group considered themselves cured, in contrast to $6.9 \%$ in the placebo group. Furthermore, $18.7 \%$ reported improvement in contrast to $13.8 \%$ in the other group. $26.6 \%$ of the participants in the active group reported unchanged status versus $48.3 \%$ in the placebo group. Worsening of symptoms was reported by $9.4 \%$ in the active group versus $31 \%$ of the female patients in the other group (10).

\section{Discussion}

Considering that conservative methods improve the initial state in a significant percentage and increase satisfaction with the quality of life, they have been recommended as the first option for treatment of urinary incontinence. One of the most widely studied methods is BF therapy, either as a sole treatment or in combination with other treatment methods.

$\mathrm{BF}$ is a useful method because it uses visual, auditory, or tactile signals to give feedback and promotes correct contraction and visualization of muscle activity, because many women are unaware of how to contract their muscles.

It has been proven that BF has a positive effect on motivation and that it encourages constant exercise of pelvic muscles $(8,25)$. Furthermore, women in assisted BF therapy achieve results which are almost double compared to self-conducted Kegel exercises (26). It should be noted that it is very important to perform the exercises correctly because the likelihood that positive results will last for the next 10 years is increased by 66\% if Kegel exercises in the initial stage are successfully and positively evaluated (27).

Past research which compared exercises designed for strengthening PFM with or without BF therapy showed different data related to success and effectiveness. While some studies reported significantly greater improvement and a decrease of symptoms of urinary incontinence after BF therapy, others did not note significant differences which would confirm this theory $(7,10,22-24)$.

For the past 30 years, many studies have been conducted to prove the efficacy of BF therapy in the treatment of urinary incontinence. 
Berghmans conducted the first larger study in the mid-1990s. The author found that BF in combination with Kegel exercises does not significantly improve the symptoms of incontinence when compared to self-performed Kegel exercises (60\%:53\%) (12) by performing a systematic review of the literature published in the period of 1980-1996 and conducting a qualitative meta-analysis. This is contrary to the analysis by De Kruif, Wegan and Weatherall who determined that combined BF therapy is more efficient than individual Kegel exercises $(28,29)$. De Kruif et al. searched MEDLINE and Excerpta Medica and then compared six studies which described PME alone to PME combined with BF. Of these 6 studies, 2 reported statistically significant differences between groups on any outcome measure. The other studies described better outcomes for the BF groups, but authors considered that results were not statistically valid (28). Weatherall performed a quantitative meta-analysis based on the systematic review by Berghmans et al., Burns et al. and Glavind et al. using the number of cured patients as an outcome. Data identified in a previous systematic review were subjected to pooled analysis of odds ratios for the size and variability of each trial. Weatherall identified different conclusions from those in the systematic review mainly due to insufficient power to detect differences in the individual trials, a limitation partially ameliorated by quantitative meta-analysis (29).

Barbosa with her associates (2011) conducted a systematic review of literature and analysed Berghmans's and two more studies and reached the same conclusion: Kegel exercises are equally effective with or without BF (30).

Pages et al. (2001) compared and analysed individual BF training with group psychological therapy program on the sample of forty women with SUI for 12 weeks. Both therapies were shown to be equally effective in reducing nocturia, but BF therapy resulted in a better subjective outcome (62\%) as opposed to the psychological therapy group (28\%) (31).

Fitz et al. (2012) proved that Kegel exercises in combination with BF improve pelvic floor muscle function, reduce urinary symptoms and improve the quality of life (32), while Yoo (2011) evaluated the efficacy of BF therapy combined with Kegel exercises for urinary incontinence three months after the completion of treatment (33). Successful therapy meant that no additional treatment was needed, but if a surgical procedure was required after BF therapy, the treatment was evaluated negatively. The study employed a retrospective analysis of the clinical data of 86 women. Treatment was successful for $57 \%$ of women who required no further therapy by other methods (33).

Different, non-standardized BF devices, different outcome measures, different measurement methods and indicators of the strength of particular muscle groups, different methods of education and conducting Kegel exercises (individually, in a group, at home or in clinical environment), and different periods of follow-up are just some of the deficiencies and unevenness in results of the same method and different authors.

BF therapy is less time-consuming and more private, but it is more invasive and costly, which is the reason why women disliked this method. The second reason is the use of a vaginal device which is unpleasant for many women (34-36). A non-vaginal device, such as transabdominal ultrasound, may be required in the future (37) because some authors reported pain while training because of the use of tampons or diaphragms, especially in middle-aged and elderly women who were not accustomed to using tampons and diaphragms $(34,36)$.

In future similar research, the focus should be on BF standardization, in a more homogeneous group because it is difficult to determine the relative effectiveness of BF and Kegel exercises on different outcome measures. Further studies with larger samples designed to consider frequency and duration of follow-up, as well as adherence, are necessary.

\section{Conclusion}

The findings of this systematic review have demonstrated that correctly taught BF combined with Kegel exercises and electrical stimulation are an effective treatment for the majority of patients with SUI. The evidence has demonstrated that the combination of $\mathrm{BF}$ and Kegel exercises is the best non-surgical treatment for SUI. Out of a total of 5 analysed articles, 4 of them showed that BF, as an additional method, has a positive effect on the increase of pelvic floor 
muscle strength and thus on the reduction of involuntarily urination. Only one study suggested that no additive effect of BF training was found and that there were no differences in the outcome between the PFM training with or without BF, and the authors thought that BF was not necessary as a standard add-on treatment.

BF is useful as an adjunct for strengthening PFM, as well as its volume and function. The use of sophisticated equipment such as various BF devices achieves significantly better results in a shorter period of time and is proven to affect the patient's motivation.

\section{References}

1. IrwinDE,KoppZS,AgatepB,Milsoml,AbramsP.Worldwide prevalence estimates of lower urinary tract symptoms, overactive bladder, urinary incontinence and bladder outlet obstruction. BJU Int. 2011;08(7):1132-1138. https://doi.org /10.1111/j.1464-410X.2010.09993

2. Mendes A, Rodolpho JR, Hoga LA. Non-pharmacological and non-surgical treatments for female urinary incontinence:an integrative review. Appl Nurs Res. 2016; 31:146-53. https://doi.org/10.1016/j. apnr.2016.02.005

3. Eapen RS, Radomski SB. Gender differences in overactive bladder. Can J Urol. 2016;23(1) 2-9.

4. Cherniack PE. Biofeedback and other therapies for the treatment of Urinary incontinence in the Elderly. Altern Med Rev. 2006; 11(3):224-231.

5. Perera J, Kirthinanda DS, Wijeratne S, Wickramarachchi TK. Descriptive cross sectional study on prevalen ce,perceptions,predisposing factors and health seeking behavior of women with stress urinary incontinence. BMC Wom Health. 2014;14:78. https://doi. org/10.1186/1472-6874-14-78

6. Dass AK, Lo TS, Khanuengkitkong S, Tan YL. Diagnosis and conservative management of female stress urinary incontinence. Gynecol Min Invasive Ther. 2013;2(2):4851. https://doi.org/10.1016/j.gmit.2013.02.005

7. Hirakawa T, Suzuki S, Kato K, Gotoh M, Yoshikawa Y. Randomized controlled trial of pelvic floor muscle training with or without biofeedback for urinary incontinence. Int Urogynecol J. 2013;24(8):1347-54. doi: 10.1007/s00192-012-2012-8.

8. Rett MT, Simoes JA, Herrmann V, Pinto CLB, Marques AA, Morais SS. Management of stress urinary incontinence with surface electromyography-assisted bio- feedback in women of reproductive age. Phys Ther. 2007; 87(2):36-42.

9. Seong HP, Kang CB. Effect of Kegel exercises on the management of female stress urinary incontinence: $A$ systematic review of randomized controlled trials. Adv Nurs. 2014; http://dx.doi.org/10.1155/2014/640262

10. Terlikowski R, Dobrzycka B, Kinalski M, Moskal AK, Terlikowski SJ. Transvaginal electrical stimulation with surface EMG Biofeedback in managing stress urinary incontinence in women of premenopausal age: a double-blind, placebo-controlled, randomized clinical trial. Int Urogynecol ] 2013;24:1631-38. https://doi. org/10.1007/s00192-013-2071-5

11. Imamura M, Jenkinson D, Wallace S, Buckley B, Vale $L$, Pickard R. Conservative treatment options for women with stress urinary incontinence: clinical update. $\mathrm{Br}$ J Gen Pract. 2013;63:218-220. doi: 10.3399/ bjgp13X665477

12. Berghmans LCM, Frederiks CMA, de Bie RA, Weil EHJ, Smeets LWH, van Waalwijk van Doorn ESC at al. Efficacy of biofeedback, when included with pelvic floor muscle exercise treatment, for genuine stress incontinence. Neurourol Urodyn. 1996;15:37-52.

13. Bogner HR, Gallo JJ, Sammel MD, Ford DE, Armenian $H K$, Eaton WW. Urinary incontinence and psychological distress in community-dwelling older adults. J Amer Ger Soc. 2002; 50(3): 489-495. DOl: 10.1046/j.15325415.2002.50115.x

14. Oreskovic S. Contemporary approach to diagnosis and treatment of women with urinary incontinence and pelvic defects. Medicus.2006; 15(2):257-68.

15. Sampselle CM,DeLancey JOL. Anatomy of female continence. J WOCN. 1998;25(2):63-74. https://doi. org/10.1016/S1071-5754(98)90091-2

16. Price N, Dawood R, Jackson SR. Pelvic floor exercise for urinary incontinence: A systematic literature review. Maturitas. 2010; 67(4):309-15. https://doi. org/10.1016/j.maturitas.2010.08.004

17. Herderschee R, Hay-Smith ECJ, Herbison GP, Roovers JP. Feedback or biofeedback to augment pelvic floor muscle training for urinary incontinence in women: shortened version of a Cochraine systematic review. Neurourol Urodynam. 2012;32(4):325-29. doi: 10.1002/14651858.CD009252

18. Bo K, Talseth T, Holme I. Single blind, randomised controlled trial of pelvic floor exercises, electrical stimulation, vaginal cones, and no treatment in management of genuine stress incontinence in women. BMJ.1999;318(7182): 487-493.

19. Nad Skegro S. Conservative treatment of stress urinary incontinence and pelvic floor defects. Medicus.2015; 25(1):25-32.

20. Bø K. Effect of electrical stimulation on stress urinary incontinence. Clinical outcome and practical recommendations based on randomized controlled trials. Acta Obstet Gynecol. 1998;77(168):3-11. 
21. Capelini MV, Riccetto CL, Dambros M, Tamanini JT, Herrmann V, Mulle V. Pelvic Floor Exercises with Biofeedback for Stress Urinary Incontinence. International Braz J Urol. 2006;32(4)462-469. http://dx.doi. org/10.1590/S1677-55382006000400015

22. Ibrahim IK, Hameed MMA, Taher EM, Shaheen EM, Ali Gawdet Elsawy MS. Efficacy of biofeedback-assisted pelvic floor muscle training in females with pelvic floor dysfunction. Alex J Med. 2015;51:137-42.

23. Ong TA, Khong SY, Ng KL, Ting JRS, Kamal N, Yeoh WS et al. Using the Vibrance Kegel Device with pelvic floor muscle exercise for stress urinary incontinence: a randomized controlled pilot study. Urol.2015; 86(3):487-91.

24. Yeung KW, Lui KI, Ho WF, Li CM, Fan CW, Tang CN. Evaluation of treatment outcomes in pelvic floor muscle training with biofeedback versus intra-vaginal electrical stimulation in women with urinary incontinence in Hong Kong Pamela Youde Nethersole Eastern Hospital. Urology Sci. 2016;27:24-35.

25. Schmidt AP, Sanches PRS, Silva DP Jr, Ramos JGL, Nohama P. A new pelvic muscle trainer for the treatment of urinary incontinence. Int J Gynecol Obstet. 2009; 105:218-22. https://doi.org/10.1016/j. ijgo.2009.01.013

26. Herderschee R, Hay-Smith EJ, Herbison GP, Roovers JP, Heineman MJ. Feedback or biofeedback to augment pelvic floor muscle training for urinary incontinence in women. Cochraine database Syst Rev. 2011 Jul 6;(7):CD009252. doi: 10.1002/14651858.CD009252.

27. Cammu H, Van Nylen M, Amy JJ. A 10-year follow-up after Kegel pelvic floor muscle exercises for genuine stress incontinence. Br J Urol Int. 2000;85(6):655-58.

28. de Kruif YP, van Wegen EEH. Pelvic floor muscle exercise therapy with myofeedback for women with stress urinary incontinence: a meta-analysis. Physiother. 1996; 82(2): 107-13. http://dx.doi.org/10.1016/ s0031-9406(05)66964-7

29. Weatherall M. Biofeedback or pelvic floor muscles exercise for female genuine stress incontinence: $A$ meta-analysis of trials identified in a systematic review. BJU Inter. 1999; 83(9):1015-6.
30. Barbosa LMA, Bezerra Los D, Bezerra de Silva I, Ferreira Anselmo CWS. The effectiveness of biofeedback in treatment of women with stress urinary incontinence:a systematic review. Rev Bras Saude Matern Infant. 2011;11(3):217-25.

31. Pages IH, Jahr S, Schaufele MK, Conradi E. Comparative analysis of biofeedback and physical therapy for treatment of urinary stress incontinence in women. Am J Phys Med Rehabil. 2001;80(7):494-502.

32. Fitz FF, Resende AP, Stupp L, Costa TF, Sartori MG, Girao $M J$ et al. Effect the adding of biofeedback to the training of the pelvic floor muscles to treatment of stress urinary incontinence. Rev Bras Ginecol Obstet. 2012;34(11):505-10.

33. Yoo EH, Kim YM, Kim D. Factors predicting the response to biofeedback-assisted pelvic floor muscle training for urinary incontinence. Inter J Gynecol Obstet. 2011;112:179-181.

34. Prashar S, Simons A, Bryant C, Dowell C, Moore KH. Attitudes to vaginal/urethral touching and device placement in women with urinary incontinence. Int Urogynecol J Pelvic Floor Dysfunct. 2000; 11:4-8.

35. Mørkved S, Bø K, Fjørtoft T. Effect of adding biofeedback to pelvic floor muscle training to treat urodynamic stress incontinence. Obstet Gynecol. 2002; 100(4):730-9.

36. Aukee $\mathrm{P}$, Immonen P, Penttinen J, Laippala P, Airaksinen 0 . Increase in pelvic floor muscle activity after 12 weeks' training: a randomized prospective pilot study. Urology. 2002; 60:1020-1024.

37. Chehrehrazi M, Arab AM, Karimi N, Zargham M. Assessment of pelvic floor muscle contraction in stress urinary incontinent women: comparison between transabdominal ultrasound and perineometry. IntUrogynecol J Pelvic Floor Dysfunct. 2009; 20:14911496. https://doi.org/10.1007/s00192-009-0977-8. 


\section{DJELOTVORNOST BIOLOŠKE POVRATNE SPREGE (BIOFEEDBACKA) KAO KONZERVATIVNE METODE LIJEČENJA STRESNE URINARNE INKONTINENCIJE KOD ŽENA}

\section{Sažetak}

Cilj je ovog rada sustavnim pregledom literature utvrditi svrhu i djelotvornost primjene biološke povratne sprege (engl. biofeedback) kod liječenja stresne inkontinencije.

Materijali i metode. Pretraživanjem baze podataka MEDLINE pronađeni su članci povezani s metodom liječenja inkontinencije biofeedbackom. Ključne riječi prema kojima se pretraživala baza bile su: "biofeedback”, „Žene", „stresna urinarna inkontinencija”. U analizu su bili uključeni samo recenzirani, u cijelosti objavljeni članci, s rezultatima liječenja stresne urinarne inkontinencije (SUI) s pomoću biofeedbacka kod žena u dobi od najmanje 18 godina, iz svih dijelova svijeta, bez obzira na to u kojem se okuženju odvijala terapija. Kriteriji uključivanja bili su izvorna istraživanja ne starija od pet godina i pisana na engleskom jeziku.

Rezultati. Pretražujući bazu s ključnim riječima pronađena su ukupno 123 članka. Daljnjom analizom utvrđeno je da ih 32 odgovara kriterijima pretraživanja. U konačnu analizu uvršteno je pet radova. Analizirane studije bile su iz različitih dijelova svijeta: Egipat, Poljska, Kina, Malezija i Japan. Dva su članka iz 2013. i 2015. godine, a jedan iz 2016. godine. Tri studije procjenjivale su učinkovitost terapije biofeedbackom u usporedbi s Kegelovim vježbama, a dvije studije u usporedbi s elektrostimulacijom.

Zaključak. lako gotovo sve studije (četiri od pet analiziranih) izvještavaju o pozitivnom utjecaju terapije biofeedbackom u liječenju stresne inkontinencije, potrebna su daljnja istraživanja na homogenijoj skupini i sa standardiziranim protokolima.
Ključne riječi: stresna urinarna inkontinencija, biofeedback, žene 